\title{
Vita communis in Central European Monastic Landscapes
}

\author{
Christina Lutter
}

Addressing Community

The Visions of Community project (VISCOM) proposes a transcultural concept of community as a frame of reference to compare interrelated social and symbolic categories of identification and belonging that are at work on diverse societal levels. Among other factors, they are responsible for the making and un-making of social groups defined, for instance, by religious and ethnic qualities as well as through criteria related to ancestry and kinship, or their position in entangled social and political networks. ${ }^{1}$

Community can be addressed both as a social and as an affective category. ${ }^{2}$ Hence, in what follows, I refer to community in terms of symbolic, yet dynamic representations of belonging that are narrated and enacted, imagined and felt in a variety of ways. Visions of communities hold social groups together. They are on the one hand expressions of belonging to social groups, providing such groups with specific norms and values, narratives and symbols of togetherness and solidarity; but on the other hand they may also be articulations of perceived difference and used for exclusion. Importantly, community involves social practices as well—community is not only imagined, but also "done", especially by means of regular exchanges and interactions that play a crucial role in processes of community construction. ${ }^{3}$

1 See the introduction to this volume by Walter Pohl and its conclusion by Andre Gingrich; $\mathrm{cf}$. also Gingrich/Lutter, "Visions of Community", on the programme viscom: "Visions of Community: Comparative Approaches to Ethnicity, Region and Empire", funded by the Austrian Science Fund (FWF) 2011-2019 through its Special Research Realm (SFB) programme as F-42. Special thanks for important feedback and discussion above all to my coeditors Eirik Hovden and Walter Pohl, to the other contributors to this collection, especially those to this section of the volume, Andre Gingrich and Elisabeth Gruber; as well as to Mirko Breitenstein, Franz Felten, and Jonathan Lyon.

2 Lutter, "Social Groups", and ead., "Comparative Approaches"; seminal on the latter aspect is Rosenwein, Emotional Communities and most recently ead., Generations of Feeling.

3 Anderson, Imagined Communities; Cohen, The Symbolic Construction of Community, discussed in Gingrich/Lutter, "Visions of Community". For European medieval history see Otto

(C) CHRISTINA LUTTER, 2016 | DOI 10.1163/9789004315693_017

This is an open access chapter distributed under the terms of the Creative Commons Attribution-

Noncommercial-NoDerivatives 3.o Unported (CC-BY-NC-ND 3.o) License. 
This set of defining elements can be used comparatively to structure our search for traces of community in different historical settings and types of source material. In what contexts and by what means were people and groups identified and classified according to perceptions of their shared properties? When and how did people specifically link such markers of "groupness" to the specific quality of community? ${ }^{4}$ When and where did they explicitly address community, or else implicitly refer to it by means of symbols? ${ }^{5}$ What other forms of communicating belonging or togetherness do we find in our source material, e.g. rhetorical or narrative strategies, hints at ritual, or performative practices detectable in written texts as well as in pictorial and material evidence?

One of the advantages of a transcultural concept of community as just outlined is that it allows for a broader assessment of relations and translations between our own analytical terminology and the semantics of our sources, and also between the terminologies of the sources in the different geographical regions that are the objects of viscom's comparative endeavour. ${ }^{6}$

Concepts of Christian monastic community can serve as appropriate test cases to explore these entangled dimensions: first, because of the long-lasting societal importance of this specific way of life throughout medieval Europe; second, because of its impact on and entanglement with a variety of other social fields; third, because some key texts of medieval monasticism directly address community, expressly using the term vita communis, while also developing a related figurative vocabulary. Moreover these texts refer to it as a specific way of life defined by regular practice as a primary instrument for adopting, training — and hence doing community. ${ }^{7}$

G. Oexle's work on social groups, e.g. the section "Soziale Gruppen in der Gesellschaft", in his (re)printed essays Die Wirklichkeit und das Wissen, 441-687.

4 The term "groupness" was coined by Brubaker/Cooper, "Beyond Identity", in their critical assessment of the concept of identity.

5 On this set of questions see particularly the contributions to the first section of this volume.

6 Lutter, "Comparative approaches", 13-19. The nature of the-often fragmented-evidence and the problems thereby raised for terminological questions is an issue tackled in most contributions to this section, e.g. Fermer, "Among Teachers and Monastic Enclaves", on late medieval Tibet.

7 Derda, Vita communis. Klaus Schreiner's and Gert Melville's work is pioneering, see e.g. Schreiner, Gemeinsam leben; Melville, "Innovationskraft" with extensive references. On historical and anthropological approaches to performative aspects of symbolic constructions of meaning see Martschukat/Patzold, Geschichtswissenschaft und "performative turn"; Korom, The Anthropology of Performance. For comparative aspects see for example the contributions by Eirik Hovden and Mathias Fermer in this volume as well as Vanderputten's concept of 
I will first look at the formative period of Christian monasticism and the career of the vita communis concept in 11th- and 12th-century reform monasticism, drawing on an approach that links visions of an apostolic way of life to their relation to social groups in the secular world. ${ }^{8}$ Second, I will trace the concept's significance for Central European monastic houses: does the source material provide distinguishable articulations of belonging that address specific concepts and forms of community life within and beyond these monasteries' walls?

\section{Vita communis_-Ordo Disciplinae}

In occidental Christianity, community is most obviously connected to the key concept of vita communis, established as a way of living together in the name of Christ. Its main features were developed by early Christian spiritual leaders, such as Pachomios (292-346), Basilius (d. 379), John Cassian (360-430/435), and — with the longest lasting impact—St Augustine (d. 430). ${ }^{9}$ He turned the biblical model of vita apostolica, which promoted the community of Christ's earliest followers regardless of their ancestry or rank, ethnicity or gender, into a powerful norm of coenobitic life. His vision of community was modelled on the apostolic life, with its key symbols of living together as one heart and one soul. Augustine's societas sancta, sharing all possessions in the spirit of love and fraternity, became one of the most successful monastic rules in medieval Europe. $^{10}$

While the biblical concept of community also plays an important role in the other early rules, most of them elaborated on alternative key elements of coenobitic life: above all, ascetic - if moderate and shared-exercise and discipline of conduct in each respect of daily routine were conceived of as crucial for each member's path to salvation. ${ }^{11}$ Correspondingly, and in contrast to the key vocabulary of Augustine's Praecepta, other early rules, when they refer

"communities of practice" as proposed in this volume, and also id., Reform as Process and id., "Communities of Practice".

8 Oexle, "Max Weber und das Mönchtum", 311-34; id., "Koinos bios", 470-95.

9 For a comparison of these normative texts see Derda, Vita communis; Oexle, "Koinos bios"; Schreiner, "Communio", 205-41, here 219-23.

10 Acts 4:32: erat cor unum et anima una...erant illis omnia communia; and La règle de Saint Augustin, ed. Verheijen, 1:417. Cf. Schreiner, "Ein Herz und eine Seele" and id., "Communio". On this notion in the context of the Carolingian concept of ecclesia cf. Kramer, "Teaching Emperors", in this volume, p. 326-29 with further references.

11 Leyser, Authority and Asceticism; Diem, Das monastische Experiment. 
to monastic life, use the terms coenobiotarum disciplina or ordo disciplinae rather than Augustine's community-based vocabulary. ${ }^{12}$

Augustine's societas sancta, based on the biblical ecclesia primitiva united through the idea of entwined love to God and to one's neighbour, on the one hand, and the rule of St Benedict (d. 547) on the other hand, provided two key normative strands of many debates that were a constant part of recurrent religious reform movements. Benedict's rule was designed as a schola servitii (prol. 45) and was thus conceptually closer to the discipline-oriented coenobitical projects of Augustine's predecessors. ${ }^{13}$ At first glance, Augustine's Praecepta and Benedict's rule even seem to follow opposing principles of love and unanimity versus discipline and obedience. Moreover, and contrary to Augustine, it appears that Benedict does not care much about discussing community as an issue. In fact, he does not even use the term community-except once, when quoting the Acts of the Apostles (4:32) on the shared property of Christ's followers (c. 33).

Nevertheless, Benedict leaves no doubt about the advantages of coenobitic life as opposed to individual asceticism. If his focus is on the spiritual progress of the individual soul, he considers this endeavour to be best realized under the guidance of the abbot and in the shared environment of one's fellow brothers. ${ }^{14}$ Chapter 7 describes the 12 grades of humility as a progress of ascetic exercise from fear of God to love for God. Disciplina regularis, one of Benedict's key terms, is warranted by fear of God, obedience to the abbot and control by the fellow community members. Hence, even while not using the vocabulary of community, Benedict is clearly addressing vita communis by addressing monastic discipline as a way of life. His rule provides detailed instructions for all types of shared daily routine — prayer and liturgy, learning and meals—and

12 Derda, Vita communis, 86-92; Oexle, "Koinos bios", 488-89. The body of rules ascribed to Augustine consists of three parts: the most famous Praecepta; a rule for women (regularis informatio) with an admonishing letter (obiurgatio) to the specific community it was addressed to serving as a preface, and operative instructions (ordo monasterii) for the implementation of the Praecepta, which are much stricter than the more general rule. In the reception of these normative texts during the Middle Ages Praecepta and ordo monasterii were often integrated and adapted into new forms of "mixed" rules; cf. Schreiner, "Communio", 208-11.

13 Derda, Vita communis, 135-82; Melville, Klöster, 35-42, provides a recent overview. The vast literature on monastic regulations is readily accessible through the vita regularis series, see http://fovog.de/vitaregdt.html.

14 The seminal study on meanings of monastic community based on 11th and 12th century reform treatises from Benedictine and Cistercian reform monasteries as well as by regular canons is Bynum, Jesus as Mother, here 59 and 76-77; cf. Derda, Vita communis, 139-49. 
correspondingly, of different grades of excommunication, i.e. of being excluded from the monastic body (corpus monasterii, c. 44,5) as a consequence of each and every instance of breaking the rule. ${ }^{15}$

Looking at the importance that Benedict and other late antique and early medieval rules, including Augustine's ordo monasterii, attributed to regular practice it becomes clear that-beyond the semantic uses of the term-vita communis was basically defined by coenobitic discipline and liturgical routine, by regularly and performatively adopting a specific habitus. Individuals' inner affective lives were conceived of as fundamentally related to their external behaviour. It was this habitus, representative of a specific way of community life, that made it distinguishable from others; and in turn members of specific monasteries, movements or orders conceived of themselves as being part of communities with specific traits. ${ }^{16}$ Individual members of social groups outside monasteries formed new groups inside monastic space, and, both by complying with visions of community and by means of regular practice, these groups were constructed into "imagined communities".

\section{The Double Dialectics of Occidental Monasticism}

The dialectic between community in terms of love and fraternity, as opposed to community in terms of discipline and exercise, corresponds to another constitutive tension deeply built into Christian monasticism: the one between, on the one hand, the aim and claim of turning away from the world to increase religious people's own and the world's chances of salvation, and on the other hand of constantly relating to the world through acts of charity and prayer in exchange for donations. Hence monastic life was fundamentally connected to the secular world. ${ }^{17}$

15 This was also common practice in high and late medieval orders drawing on Benedict's rule, cf. Füser, Mönche im Konflikt, and more specifically Kramer, “Teaching Emperors”, in this section. On the importance of routine and practice-oriented aspects in Tibetan communities see Fermer, "Among Teachers and Monastic Enclaves", in this section.

16 Derda, Vita communis, 86-93, 120-23, 171-78; Bynum, Jesus as Mother, 61-62, Melville, Klöster, 273-85. On the multiple ways of conceiving of the relations between homo interior and homo exterior see Bynum, "Body and Soul"; cf. also Lentes, "Andacht und Gebärde", and Schnell, "Wer sieht das Unsichtbare", 86-93.

17 On European monasticism cf. Schreiner, "Mönchsein", 557-620; recently e.g. Melville et al., eds., Klöster im Mittelalter zwischen Jenseits und Welt. This is a point made in several contributions to this section - if in a variety of different ways - when it comes to assessing the validity of the term "enclaves" as our object of comparison. 
Emerging during the transformation of the Roman world, monastic communities played an integral part in this complex political and societal process. ${ }^{18}$ This is what Otto G. Oexle highlights when he draws on the Weberian differentiation between asceticism based on total withdrawal from the world as opposed to asceticism within the world. The close relations that coenobitic religious institutions continued to have to the social world outside their walls help explain their societal impact and sustainable achievements. Even more, according to Oexle, this long-term success can only be understood if the specific traits of a methodological and disciplined monastic way of life are related to the specific quality of religious communities as social groups. This is most obvious in the context of the Roman Empire's urban culture. ${ }^{19}$ Augustine himself had developed his community concept in this environment even before his conversion to Christendom, based on his personal experience with a circle of close friends committed to merging their possessions to live from them together, as he reports in his Confessiones (vI, 14). With them, he initially wanted to establish a community of dialogue between like-minded people, located in the countryside and thus remote from bustling daily routines, but yet connected to them. ${ }^{20}$

Hence it does not seem a coincidence that from the 11th century onwards Augustine's ideas and vocabulary were specifically taken up in religious movements that aimed at a broader societal renewal, which among other factors resulted from the fundamental contest between spiritual and secular powers and affected concepts of negotiated governance as well as new forms of urban and rural communal organization and related new concepts of community. ${ }^{21}$ During the history of Western monasticism, the tension between-in fact interrelated- "love-based" and "discipline-based" visions of community had always been a defining moment whenever there was a call for religious reform, as the tension between withdrawal from and entanglement with the secular world had been. The complex relations between the political, economic, and pastoral tasks of religious communities increased the challenge to balance vita activa and vita contemplativa according to Gregory the Great's (d. 604) Regula

\footnotetext{
18 Brown, The Rise of Western Christendom.

19 Oexle, "Koinos bios", 476-80.

20 References and discussion in Schreiner, "Communio", 213-14.

21 Haverkamp, "Neue Formen von Bindung und Ausgrenzung", 85-122; Weinfurter, "Die Macht der Reformidee", 13-39; Breitenstein et al., eds., Innovation in Klöstern und Orden; cf. the contributions to the section on urban communities in this volume. For a comparison to earlier European reform movements see Kramer, "Teaching Emperors", in this section.
} 
pastoralis. ${ }^{22}$ Concepts of how to renovate ideals and practices of living together were taken up and rephrased according to Augustinian visions of apostolic community on the one hand and a call for stricter discipline to realize them on the other. Thus the European monastic reform movements of the 11th and 12th centuries generated a particularly wide variety of partly experimental and sometimes only temporary new forms of spiritual life. ${ }^{23}$

Numerous foundational texts, reform statutes, constitutions, reform treatises and commentaries, especially written by regular canons, Premonstratensians, and later Dominicans and Augustinian hermits-to mention just some of the most successful communities-drew on Augustine's community ideal, which at once provided clarity and yet flexibility, as well as avoided extreme ascetic rigor. ${ }^{24}$ Their authors used both its terminology and metaphorical imagery, adapting them in a variety of ways into new "mixed rules", thus reflecting different claims and standards of disciplinary practice and of institutionalization. In such texts, community is variously addressed as societas sancta, communio and vita communis; key concepts are its members' unity of concord (unitas concordiae) and unanimity (unanimitas), love (caritas), and fraternity (fraternitas), socially articulated by sharing everything (omnia communia) and symbolically by being one heart and one soul (cor unum et anima una). ${ }^{25}$

A famous example is Norbert of Xanten (d. 1134), reform canon and founder of Prémontré, who struggled —as stressed in his vita—deciding which rule this new community should follow to best fulfil the principles of a truly apostolic life. He opted for Augustine's Praecepta, and by the mid-12th century, after a decade-long process of negotiations, the Premonstratensian Liber consuetudinum embodied the growing movement's statutes and consuetudines, their by then formally established way of life. It opens with an exhortation to be one heart and one soul and stresses the importance of unity of inward conviction and outward comportment, expressed by a uniformity of liturgy, discipline, and habitus. ${ }^{26}$

22 Gregorius Magnus, Liber regulae pastoris, ed. Rommel; cf. Straw, Gregory the Great.

23 Constable, "Religious Communities".

24 Schreiner, "Communio", 239.

25 On various forms of adaptation in different religious movements and orders see the contributions in: Melville/Müller, eds., Regula Sancti Augustini. For a comparative assessment of selected European examples see ibid., Schreiner, "Ein Herz und eine Seele", 14-15 and 43, and id., "Communio", 224-41.

26 References ibid., 224-25 and more comprehensively Bomm, "Augustinusregel” and Ehlers-Kisseler, "Norm und Praxis". 
In addition, the large textual legacy of the reform movements that arose from Benedictine monasticism and thus drew on Benedict's rule, most notably texts written in the context of the Cistercian order, reflect shifts in community concepts. They were among others necessitated by increased pastoral tasks, and related to theological considerations of how God could best be served, not by focusing only on the individual souls of monks and nuns in monasteries remote from the world, but also through the service of one's neighbour both inside the spiritual community and beyond it. A turn to an increasingly affective theology stressing love and compassion, the imitation of good examples of others, and personal experience as opposed to merely intellectual learning as a means of progress of the individual soul within the community are some of the most significant features of these reform strands. ${ }^{27}$ Thus the tension between "love-based" and "discipline-based" elements of vita communis remained as defining as their integration was an issue. Many reform texts moved beyond the clear-cut conceptual realm of spiritual legacies or rules. They discussed ideas stemming from different traditions, partly engaged with pastoral experience, which often resulted in new rules or constitutions combining elements from a variety of older models and adapting them according to contextually specific requirements that related to all sorts of political, economic, and social aspects of community life. Still-their variety notwithstanding - as these normative texts present ideal visions of community they rarely reflect upon this social background, nor on the actors of community, i.e. religious men and women, or their personal relations and interactions.

Recent research on medieval religious communities has therefore started to consider a wider range of source material to get a fuller picture of what the specific spiritual profile of a religious community, movement, or order might have been, and to what extent normative community concepts as represented in the rules of St Augustine, St Benedict, or other key spiritual thinkers made a real difference in their contextually specific implementation. If we consider that vita communis, according to most rules, fundamentally consisted in regular community practice, it is even more imperative to broaden the evidence base to understand why people in a given social environment and spiritual

27 Bynum, Jesus as Mother, 63-77 for similarities and differences between models developed by regular canons, reformed Benedictines, and Cistercians; for the latter see Boquet, L'ordre de l'affect. The variety of ways of conceiving of "learning" is highlighted by all members of this section and the respective viscom working group; see Kramer, introduction to this section on communities of learning in recent comparative research see the excellent overview by Steckel, Networks of Learning, esp. pp. 191-202. 
context opted for a particular religious movement and its vision of community to which to devote their lives. ${ }^{28}$

\section{Central European Monastic Landscapes}

I now want to consider these issues by turning to Central European monastic landscapes and by moving beyond the traditional divide of focusing on either the spiritual or the social-including material-aspects of religious life. ${ }^{29}$ What did community specifically mean in Central European regions where monastic development and reform in the high and late Middle Ages closely linked to territorial expansion - and thus often had to work in a very hands-on way? Did monastic houses in these regions actively engage in addressing and debating community, and how are their visions of community represented in the sources? The first challenge is that-abundant work on individual monastic houses or orders notwithstanding - comparative research in many regions lacks comprehensive data, while in others important work has already been achieved in this respect. ${ }^{30}$ Part of our current project therefore consists in establishing a database on monastic landscapes in Austria and Styria, Bohemia and Moravia, starting with Benedictines and Cistercians, Regular Canons, and Premonstratensians as well as Carthusians. ${ }^{31}$ This database will provide

28 McGuire, Friendship and Community; Felten, "Vergleichende Ordensgeschichte"; Schreiner, "Communio", who also coined the phrase spiritual profile, 241. Cf. also the arguments in the comments on this section by Jonathan Lyon and Steven Vanderputten.

29 For a recent general overview see Berend et al., eds., Central Europe in the Middle Ages. On the concept of monastic landscape as an instrument for comparative research cf. for instance the archaeological approach by Bond, Monastic Landscapes, or the conference Monastic Landscapes: Spiritual and Physical, organized by József Laszlovszky et al. at the Department of Medieval Studies at the Central European University (CEU) in Budapest, March 5-8, 2009 and most recently the section "Spatial Approaches to Settlement an Religion in Central Europe", in Rasson and Szénde, eds., Annual of Medieval Studies, 207-75. For an approach comparable to the one proposed here see Laszlovszky, "Crown, Gown, Town". Cf. also Czaja et al., eds., Klosterlandschaften, as well as Felten et al., eds., Landschaften, esp. the contributions by Felten and Melville on monastic landscapes, ibid., at $157^{-91}$ and $195^{-221 .}$

3o Examplary is Beatrix Romhany's work on the specifically complex situation in Hungary; see her seminal overview: Romhany, Kolostorok és társaskáptalanok a középkori Magyarországon, as well as most recently her regionally comparative study, ead., "Kolostorhálózat—-településhálózat—népesség".

31 For overviews on Austria and Styria see the Germania Benedictina series, vol. 3, 1-3: Faust/Krassnig, eds., Die benediktinischen Mönchs- und Nonnenklöster; Röhrig, ed., Die 
comprehensive information on each religious house's foundation context, its position in the political and ecclesiastical topography, and its relations to monastic houses of the same order and beyond, as well as to secular and ecclesiastical authorities. ${ }^{32}$

Bohemia and Moravia feature 50 religious foundations of these orders prior to 1350 , most prominently Benedictine and Cistercian, but also Premonstratensian. Of the 47 Austrian and Styrian houses, regular canons/canonesses are most common, followed by Benedictine and Cistercian houses. Interestingly, the Austrian lands-in contrast to Bohemia and Moravia-feature a significant number of women's communities as well as "double monasteries". ${ }^{33}$ These types of community were of special interest in religious reforms, as the concept of vita apostolica addressed men and women alike (Ac 1,14). Reformers thought about how women and men could serve God together without running into the dangers brought about by cohabitation. ${ }^{34}$ Moreover, although the ideal of enclosure was generally more strictly claimed for religious women, ${ }^{35}$ recent case studies on medieval monasticism have convincingly shown that double monasteries and women's houses served as centres of social communication that linked both communities and individual members to networks of kinship and friendship outside their walls. ${ }^{36}$ Donations were crucial to enabling religious houses to fulfil their task of prayer: When new members renounced the secular world, they traded their birth families for their new spiritual familia, yet they kept close ties to their extant networks and even reinforced personal relations. Monastic community ideals would be integrated with concepts of

bestehenden Stifte der Augustiner-Chorherren; id., ed., Die ehemaligen Stifte der AugustinerChorherren. On Cistercians no comparable handbook literature exists. For a specific case study on Benedictine "Schottenklöster" see Ó Riain, in this section. On Bohemia and Moravia Vlček et al., eds., Encyklopedie and Foltýn et al., eds., Encyklopedie provide overviews; on Augustinian canons see Röhrig, ed., Augustiner-Chorherren in Böhmen, Mähren und Ungarn; on Cistercian men's communities: Charvátová, Dějiny cisterckého rádu. The project will later extend this comparison to the Mendicant orders, and also include comparative data on Hungary.

My special thanks go to the project's collaborators Martin Haltrich, Herbert Krammer, Anna Jagošova, Edith Kapeller, and Radka Lomičkova.

33 Total: 20 male, ten female, 17 "double monasteries". A first overview based on a $\mathrm{PhD}$ thesis from 2003 is provided by Kurz, Ubi et est habitatio.

Felten, Vita religiosa sanctimonialium; Melville/Müller, eds., Female "vita religiosa"; on "double monasteries" see Elm/Parisse, Doppelklöster; Griffiths/Hotchin, Partners in Spirit; cf. also Mecham, Sacred Communities, Shared Devotions.

36 For overviews see the contributions in Hamburger et al., eds., Frauen-Kloster-Kunst, 211-311; Lutter, "Geistliche Gemeinschaften". 
affiliation from outside- the term familia for such communities is a strong case in point. ${ }^{37}$

\section{Admont}

The Benedictine double monastery of Admont in Styria, founded in 1074 by the archbishop of Salzburg initially as a community for men, developed into a key reform site in south-eastern Germany during the 12th century. It is one of the most comprehensively researched religious community of the region. ${ }^{38}$ This comparatively early foundation was influenced by the Hirsau reform, a strand of religious renewal related to the famous one of Cluny and named after its key site in the Schwarzwald. ${ }^{39}$ This religious movement strove for a particularly severe renovation of a Benedictine way of life as represented in its customs (consuetudines Hirsaugienses), out of which Admont in turn developed its own version. Programmatic reform texts and narrative accounts clearly state that Admont was proud of its disciplinary austerity and spiritual excellence, and these became central features of Admont's sense of community, which was referred to as Admuntina religio, que tunc celebris habebatur. Other key terms stress the specific profile of the ordo Admuntensis, praising its stricter discipline. ${ }^{40}$

The earliest accounts of the women's community date from around 1120, and subsequently both genders are addressed correspondingly: the women are called to fight (militare) jointly with the men in the service of God and to follow the strict regulations of everyday life just the same as their brothers. Still, the nuns' exemplary way of life is highlighted on several occasions by affirming the normative ideal of an especially strict enclosure for women. A comparable assessment characterizes the nuns' epistolary dialogue with Gerhoh of Reichersberg, a protagonist of the contemporary reform of the Augustinian canons in the region. In his letters the nuns are not only referred to as mulieres fortes and brides of Christ - both central figurative representations from the

37 Schreiner, "Consanguinitas", 176-305. Cf. Mitterauer, "Geistliche Verwandtschaft"; Borgolte, Stiftung und Memoria. Cf. the contribution by Christian Opitz on visual representations of genealogies, this volume.

38 Lutter, Geschlecht\&Wissen; Roitner, "Das Admonter Frauenkloster", and the respective contributions in Beach, ed., Manuscripts and Monastic Culture. On the political and reform context Weinfurter, Salzburger Bistumsreform is seminal. Schreiner, ed., Hirsau.

40 Arnold, "Admont", 368-69 provides the text of Admont's consuetudines and further references. 
Old Testament-but also as "incarcerated women" who by virtue of their devotion suffer in order to redeem their own and the world's sins. ${ }^{41}$

Hence spiritual evidence from this monastery clearly conforms to Benedict's discipline-based community model, which was intensified by many reform concepts elaborating on his rule. But if discipline plays an outstanding role, Admont's reform texts also display a rich affective vocabulary referring to the convent as a community of men and women united in the spirit of reform. They not only stress love and fraternity as guiding principles, but also address the personal attachments of the monks and nuns to one another. A beautifully illuminated prayer book is dedicated by a prior Johannes to "our beloved sisters". 42 Admont was exemplary in its involvement in contemporary theological debates, in which the "learned sisters" took an active part. Perhaps the most important source material is the extraordinary number of about 800 surviving, often illuminated, manuscripts, some of them expressly written for and also within the women's community. ${ }^{43}$

Thus, Benedictine reform discipline notwithstanding, personal relations and collaboration in a rather Augustinian spirit of fraternity-also reminiscent of Cistercian affective theology—are striking features of Admont's community life. This is less surprising if we consider how much contemporary theological debate crossed the borders of monastic and scholastic, and of different coenobitic, traditions. Extant manuscripts from Admont feature more than sixty medieval and early modern versions of normative textsmonastic rules, statutes, constitutions, etc.-among them seven versions of St Benedict's rule (four of them Latin, three German), two versions of Augustine's Praecepta, and one of his ordo monasterii. Admont had close spiritual and political ties, and even an official spiritual confraternity (confraternitas) with the protagonists of the canonical reform in Salzburg, sustained by a dense social and intellectual network within the archbishopric and beyond. ${ }^{4}$

41 Lutter, Geschlecht\&Wissen, 107-19. This indeed can be interpreted as a very powerful representation of the idea of a spiritual community as an "enclave".

42 Cod. Admont. 18, before fol. ir. Seeberg, Illustrationen provides a comprehensive iconographic study of the manuscript.

43 Beach, Women as Scribes; Seeberg, Illustrationen; Lutter, Geschlecht\&Wissen, $5^{6-58}$ and 61-2 on sanctimoniales litteratae; on visual representations of late medieval European religious communities cf. also Opitz, Genealogical Representations, in this volume.

44 I am grateful to Martin Haltrich for providing me with manuscript data on Admont. Weinfurter, Salzburger Bischofsreform, and id., "Die Macht der Reformidee"; cf. Mews, "Scholastic Theology"; on this type of contemporary confraternities as another form of 
A prominent case in point is the Vita magistrae, an extraordinary piece of hagiography about the head of Admont's women's community who came there from a Salzburg family around 1120. The text is preserved in Admont's copy of the Magnum Legendarium, an important legendary collection with all copies stemming from Austrian monasteries. It provides important material to understand spiritual models and their relations to monastic community building. ${ }^{45}$ The Vita refers in detail to community ideals modelled on Benedict's rule and well-known hagiographic patterns, and gives "contextually specific" information on community life: we learn that the magistra composed litterae at night and dictated them to a scribe, but also at the request of the small children wrote down vernacular verse and prose on wax tablets. The text also mentions the magistra's education prior to her entry, her noble ancestry, her powerful preaching and her relations to bishops and archbishops.

A singular letter collection, mostly concerning questions of patronage and interventions on behalf of relatives, evidences more such contacts. ${ }^{46}$ Once, several nuns intercede with the archbishop of Salzburg for their fellow brothers. Frequently they remind their male relatives of their duties towards the community. These contacts and interventions show the women's active role as members of influential families and their weight as intercessors in spiritual and secular matters. Some letters even allow glimpses of emotional issues: a sister accuses a male relative of breaking his promise and turning from the "exile" of the monastery to join his people back home, leaving her alone "in a distant land like someone deceased delivered to oblivion", separated from all her friends' consolations. ${ }^{47}$ Thus, despite all the reform rhetoric of ideal visions of community, and despite the impression that Admont's community members tried to live up to these ideals, the tension between turning from the world and being connected to it remained.

The monastery's donation charters and necrologies provide additional evidence of the different ways in which a community embedded itself within larger networks of religious and secular communities. Exceptional is the charter of 1130 by which the women's community was assigned an important part

addressing and practising community see Ó Riain, “Schottenklöster in the World”, p. 393 in this section.

45 On this collection see Ó Riain, "Magnum Legendarium". The Vita magistrae is only preserved in Cod. Admont. 25, fol. 235r-v. Text in Lutter, Geschlecht\&Wissen, 226-29; discussed ibid., Chapters 2.3 and 3.1.2.

46 The letters are edited and analysed in Beach: "Voices from a Distant Land", 34-54.

47 Ibid., $5^{2}$. 
of the monastery's revenues. It states that on entering the monastery all women would be allowed to keep money, clothes, and small domestic animals, with the sole exception of the revenues from the property they had given to Admont on their conversion. ${ }^{48}$ This corresponds with the monastery's narrative sources stressing the noble origin of its members. The community's material, social, and symbolic value grew with the number of affluent persons abandoning the secular world for a new way of spiritual life in this particular environment. Reformed monasteries did not exist outside contemporary social structures, but fulfilled an important function within them. If the secular elites took care of the economic welfare of the monasteries, these were in turn designed to provide for the benefactors' memory and spiritual welfare. The social order outside the monastery translated into visions and practices of community inside, and vice versa. ${ }^{49}$

\section{More Examples—New Perspectives}

Rarely do monastic communities in the region boast a comparable abundance of source material permitting such a nuanced picture. Still, most of them provide evidence of community life. A good example are the Cistercian monasteries in the marchae and later duchies of Austria and Styria. When Cistercian monks established their first houses in these lands, around 1130 — and over the following decades expanded their spiritual, political and economic influence by means of filiations, not least in Bohemia, Moravia, and Hungary - the focus of their endeavour differed from that of the Salzburg regular canons, from Benedictine reform monasteries like Admont, but also from Cistercian houses in the core regions of religious reform in the Rhineland, Flanders, or northern France. ${ }^{50}$

48 Zahn, ed., Urkundenbuch Steiermark, 1:170, n. 171, discussed in Lutter, Geschlecht\&Wissen, 197-200.

49 Borgolte, Stiftung und Memoria; and id., Enzyklopädie des Stiftungswesens, provides a comparative perspective; see also Dendorfer, "Gescheiterte Memoria?" Gender aspects are explicitly included in Geary, Phantoms of Remembrance; van Houts, Memory and Gender; ead., ed., Medieval Memories. Cf. Ó Riain, "Schottenklöster in the World", at in this section for another example in the respective region making the case for another pattern of patronage in Europe; for a comparative perspective see especially Eirik Hovden's contribution to this section on competing visions of welfare in medieval South Arabia.

5o Overview and perspectives in: Felten/Rösener, eds., Norm und Realität; cf. also the respective bibliography in footnotes $30-31$; on the respective region: Lutter, "Locus horroris". 
Both Heiligenkreuz, the first and most prominent foundation (1133) in Austria by the Babenberg margrave, and its daughter house Zwettl (1137/38), a foundation of the Kuenring family - the most influential Babenberg ministeriales - played an important role during the processes of territorial expansion and inner consolidation of the country until the end of the 13th century. Despite the Cistercian claim of a spiritual life in the wilderness, religious houses in these "developmental" regions were almost from the beginning connected to the emerging towns and smaller settlements in their vicinity, above all to Vienna, which developed into a central place for the Babenberg rulers around the same time. Documentary records on these mutual relations go back to exactly the time when social differentiation is evidenced by more written sources and when urban elites become visible as political communities. ${ }^{51}$

Like elsewhere in Europe, Cistercian nunneries in Central Europe were for the most part founded later than the bulk of the monks' houses. But contrary to the European trend, which shows a large number of foundations of nunneries during the $13^{\text {th }}$ century, there are only a few in the Austrian lands, Bohemia, and Moravia. ${ }^{52}$ Nevertheless, some of them provide sufficient evidence to establish pastoral relations with their mother houses, most prominently those between Heiligenkreuz and St Niklas outside the city walls of Vienna. The nunnery of St Niklas, moreover, seems to have functioned as a key site in the political confrontations between the Bohemian king Přemysl Otakar II and Rudolf I of Habsburg, and also between the former and king Bela IV of Hungary, if we believe the monk Gutolf of Heiligenkreuz, who was this nunnery's pastoral advisor in the 126os and 1270s: he used a traditional hagiographic account of a relic translation from Prague to Vienna to integrate a rare-and thus valuable-coherent historiographic assessment of what happened on the larger political scene. His report is also an excellent example of a narration of community by means of well-balanced strategies of identification, as Gutolf in fact addressed different communities, the nunnery being one of them. ${ }^{53}$

$5^{1} \quad$ Ibid., esp. 163-66; cf. Csendes, "Urban Development”, and Gruber, "The City as Commune” in this volume with further references. Material on Vienna collected in Lohrmann/Opll, eds., Regesten zur Frühgeschichte von Wien. On Cistercians and urban space cf. Rösener, "Stadthöfe der Zisterzienser".

$5^{2}$ Lutter, "Locus horroris", 166-76; Vlček, et al., eds., Encyklopedie, 116, 433-35, 483, 635-37; Foltýn et al., eds., Encyklopedie, 66-7, 589-94, 208-15, 612-20. On Cistercian nunneries in cities cf. Freed, “Urban Development” and Johanek, "Stadt und Zisterzienserinnenkonvent”.

53 Redlich/Schönbach, eds., "Translatio Sanctae Delicianae”, text 8-20; Schönbach, "Über Gutolf von Heiligenkreuz". For a detailled analysis in this context see Lutter, "Geteilte soziale Räume". The Translatio S. Delicianae provides one of the key texts of Maria Mair's VISCOM-based PhD project Visions of Community in Austrian Historiography. 
As their pastor, he makes a strong case for the shelter of the religious women, whose monastery was endangered by Hungarian raids brought about by Přemysl Otakar's expansionist politics, by using the topical motive of the necessity to especially protect women by means of enclosure. Yet, as Gutolf quite openly reports, when the nunnery was in fact struck by a Hungarian assault the women immediately found shelter in the residences and castles of their families and kin in the surrounding area. This incident caused the author, as their spiritual adviser, to support the request by abbess Margardis for a new house to be dedicated to the nuns inside the walls of Vienna in order to ensure their protection. In need of a benefactor-King Otakar, once a strong supporter of the community, did not respond to their pleas-Gutolf and Margardis turned to one of the king's most influential supporters, the burgher Paltram, who with his family proved willing and able to fulfil the community's needs. They found a place within the shelter of the city walls, and the financial means to convert it into a nunnery. Gutolf's report thus stresses both the gendered, disciplinary aspect of community construction related to the religious practice of St Niklas' women, and the gendered nature of their social networks. Later documentary records suggest that many nuns were members of regional elite families who played a crucial role in the political and military conflicts between the Bohemian king and Rudolf I of Habsburg. ${ }^{54}$ From around 1300 onward, prosopographical information on abbesses, functionaries, and members of the convent increases.

Comparable to parts of Admont's source material, Gutolf's text addresses community less theoretically but more in terms of affiliation, by means of narrative strategies that he deploys to highlight personal relations. Moreover, as in Admont, some of the Cistercian houses in Austria also provide a substantial manuscript tradition capable of broadening the picture of community articulations and of shedding light on their spiritual aspects. For instance, besides the Translatio S. Delicianae and his Historia annorum 1264-1279, Gutolf composed a life of St Scholastica, a didactic dialogue between a Cistercian and St Agnes, a Latin Grammar for the nuns of St Niklas, and a number of works for his fellow brothers in Heiligenkreuz. ${ }^{55}$ The Cistercian nunnery of St Bernhard near Horn on the Bohemian border, under the pastoral care of Heiligenkreuz's daughter house Zwettl, possesses a vernacular foundation history written around 1300 displaying a number of elements comparable to its temporal and functional equivalent, the liber fundatorum of Zwettl. Both feature a number of the elements of community construction discussed so far-in both cases

54 Opll, "St. Maria bei St. Niklas", 171-75.

55 Knapp, Die Literatur des Spätmittelalters, 2/1:38-52. 
again supported by documentary records. ${ }^{56}$ Fourteenth-century visitation protocols preserved in Bohemian and Austrian Cistercian monasteries give important insight into daily community life and discipline-oriented visions of community according to the Cistercian adaptation of St Benedict's rule, as Radka Lomičková has shown in a recent comparative analysis. ${ }^{57}$

My final example, which may provide an outlook on future research perspectives, is the important Babenberg foundation Klosterneuburg, consisting of Augustinian regular canons and two women's communities, St Magdalena and St Dorothea. Comparable to the Cistercian communities in Lower Austria and to Admont in the archbishopric of Salzburg, all of these exhibit close relations to each other as well as to the territorial lord and to regional families. Klosterneuburg was founded by margrave Leopold III in 1133-in the same year as the foundation of the Cistercian Heiligenkreuz took place. ${ }^{58}$ This is not a coincidence, but hints at Leopold's strategic use of monastic foundations during an important formative period of the Babenberg lands. Like most of the princes in the Holy Roman Empire and other Central European regions, the Babenberg relied both on religious institutions and on urban settlements to exercise their family's power in a country that was then only in the process of being formed with the help of the most important elites and their networks.

It therefore does not come as a big surprise that from the 12th century onwards the Klosterneuburg foundations feature a large number of men and women from influential families representing the regionally specific, upwardly mobile group of the ministeriales, who by the end of the 13th century constituted the country's main elite. Nor is it surprising that these people chose the community model of regular canons and canonesses, which was by definition less severe and more adaptable than other rules and thus left open more space for negotiations over personal property, living conditions, and contacts with the outside world. ${ }^{59}$

From the mid-12th century onwards, charters start documenting the popularity of the foundations among the regional elites. During the next two centuries, papal and episcopal mandates repeatedly state the necessity of limiting

$5^{6}$ On Zwettl's liber fundatorum see the contributions by Brunner, "Die Zwettler 'Bärenhaut”, 647-62 and Rössl, "Die Zwettler 'Bärenhaut”, 663-80; on St Bernhard: Andraschek-Holzer et al., eds., St. Bernhard.

57 Lomičková, “Visitationsurkunden”, 241-82, esp. 247-55 on punishment by means of different grades of exclusion from the community (excommunicatio) combined with other penalties. Cf. Oberste, Visitation und Ordensorganisation.

$5^{8}$ Brunner, Leopold, der Heilige, 158-63 and 181-83.

59 Dienst, Regionalgeschichte, 174-87. 
the number of members; from the 14th century on, visitation charters, later substantiated by often detailed data in Klosterneuburg's account books, repeatedly try to constrict and control the extravagant lifestyle both in the women's and men's communities, obviously often without success. Regulations concern private property and noble comportment—elegant clothes, carriages with up to 16 horses permitted for the prior-but also constant and unregulated contacts between both genders. The demand that St Augustine's rule should be read at least once per quarter differs considerably from Augustine's own command to have his guideline read in common once a week. ${ }^{60}$ At first glance, it seems self-explanatory that these houses located at a key political site would have opted for community models for which the flexibility of Augustine's Praecepta provided a convenient conceptual framework. Still, if we compare Admont, St Niklas and Klosterneuburg, it is also evident that they shared important features, and particularly in this respect: they were all related to centres of political power. Moreover, they represented or were close to intellectual centres producing not only manuscripts but also documentary records that help us integrate the social and spiritual aspects of community.

So how significant are the differences between key community models such as Augustine's Praecepta or the rule of St Benedict when it comes to assessing the specific profiles of these communities in a monastic landscape? The most important differences are still those arising from the inconsistent research situation. Strikingly, for instance, very little in-depth research has been undertaken thus far on the spiritual life of the large number of "double houses" in the Austrian lands following the Augustinian rule: from Klosterneuburg alone we know of more than two dozen different manuscript versions of normative texts, both in Latin and in the vernacular, let alone hagiographic collections, sermons, and didactic spiritual literature, all of them reflecting upon visions and practices of community in the ways outlined above. ${ }^{61}$ Only if we continue to relate this material to the key early medieval texts and to their contextually specific reception in reform movements and throughout monastic landscapes will we gain a more comprehensive picture of how community was in fact addressed and lived, and be able to assess comparatively the specific profile of spiritual communities in relation to their wider societal environment. At least in the European context, kinship, property, and gender cannot be separated

$60 \quad$ Zeibig, ed., Urkundenbuch Klosterneuburg, 1:67-70: visitation report by bishop Bernard of Passau from 1301, May 26; cf. Rechnungsbücher (Rb) 31/1-8 (1445-1533), Stiftsarchiv Klosterneuburg.

61 Detailed information at www.manuscripta.at, a web portal providing significant data on medieval manuscripts extant in Austrian and selected other Central European libraries. 
from either the political or spiritual practices constitutive for these institutions - or from the visions of the people who made them into communities. These additional categories help to assess the different types of community to which a given monastery might belong; at the same time they provide an interface to eventually move beyond the European phenomenon of monastic houses to engage with patterns of comparison in the parts of the VISсом project for which "monastery" is not even a specific category for defining ways of belonging to a religious community. ${ }^{62}$

\section{Bibliography}

\section{Primary Sources}

Rudolf Hanslik, ed., Benedicti Regula, Corpus Scriptorum ecclesiasticorum latinorum 75 (Vienna, 1960).

Gregorius Magnus, Liber regulae pastoris, ed. and trans. Floribert Rommel and Charles Morel, Sources Chrétiennes 381-382 (Paris, 1992).

Oswald Redlich and Anton E. Schönbach, eds., "Des Gutolf von Heiligenkreuz Translatio Sanctae Delicianae", in Sitzungsberichte der Kaiserlichen Akademie der Wissenschaften in Wien, phil.-hist. Klasse 159/2 (Vienna, 1908), 1-38.

Luc Verheijen, ed., La règle de Saint Augustin, 2 vols. (Paris, 1967).

Josef Zahn, ed., Urkundenbuch des Herzogthums Steiermark, 1 (Graz, 1876).

Hartmann Joseph Zeibig, ed., Urkundenbuch des Stiftes Klosterneuburg bis zum Ende des vierzehnten Jahrhunderts, part 1 , Fontes rerum Austriacarum 2/10 (Vienna, 1857).

\section{Secondary Literature}

Benedict Anderson, Imagined Communities: Reflections on the Origin and Spread of Nationalism, rev. ed. (1983; London, 2006).

Ralph Andraschek-Holzer et al., eds., St. Bernhard und die Zisterzienser: Neue Forschungen zu Geschichte und Kunst (St Pölten, 2001).

Klaus Arnold, "Admont und die monastische Reform des 12. Jahrhunderts", Zeitschrift der Savigny-Stiftung für Rechtsgeschichte (1972), 350-69.

Alison I. Beach, "Voices from a Distant Land: Fragments of a Twelfth Century Nun's Letter Collection”, Speculum 77 (2002), 34-54.

62 See esp. the questions raised by Hovden, "Competing Visions", in this section. Several contributors to this section highlight the temporal, regional, and social heterogeneity of spiritual communities in the respectively examined cultural realm, their quality as possible configurations that do not exclude other models, see for instance Hugon, "Enclaves of Learning", in this section. 
Alison I. Beach, Women as Scribes: Book Production and Monastic Reform in TwelfthCentury Bavaria (Cambridge, 2004).

Alison I. Beach, ed., Manuscripts and Monastic Culture: Reform and Renewal in TwelfthCentury Germany (Turnhout, 2007).

Nora Berend et al., Central Europe in the Middle Ages: Bohemia, Hungary and Poland, c.90o-c.13oo (Cambridge, 2013).

Werner Bomm, "Augustinusregel, professio canonica und Prämonstratenser im 12. Jahrhundert: Das Beispiel der Nobert-Viten, Philipps von Harvengt und Anselms von Havelberg", in Regula Sancti Augustini: Normative Grundlage differenter Verbände im Mittelalter, eds. Gert Melville and Anne Müller (Paring, 2002), 239-94. James Bond, Monastic Landscapes (Tempus, 2004).

Damien Boquet, L'ordre de l'affect au Moyen Âge: Autour de l'anthropologie affective d'Aelred de Rievaulx (Caen, 2005).

Michael Borgolte, Stiftung und Memoria, ed. Tillman Lohse, Stiftungsgeschichten 10 (Berlin, 2012).

Michael Borgolte et al., eds., Enzyklopädie des Stiftungswesens in mittelalterlichen Gesellschaften (Berlin, 2014).

Mirko Breitenstein et al., eds., Innovation in Klöstern und Orden des Hohen Mittelalters: Aspekte und Pragmatik eines Begriffs, Vita regularis 48 (Münster, 2013).

Peter Brown, The Rise of Western Christendom: Triumph and Diversity A.D. 200-100o (Oxford, 1996).

Rogers Brubaker and Frederick Cooper, "Beyond Identity", Theory and Society 29 (2000), 1-47.

Karl Brunner, "Die Zwettler 'Bärenhaut' - Versuch einer Einordnung”, in Geschichtsschreibung und Geschichtsbewußtsein im späten Mittelalter, ed. Hans Patze, Vorträge und Forschungen 31 (Sigmaringen, 1987), 647-62.

Karl Brunner, Leopold, der Heilige: Ein Portrait aus dem Frühling des Mittelalters (Vienna, 2009).

Caroline Bynum, Jesus as Mother: Studies in the Spirituality of the High Middle Ages (Berkeley, 1982).

Caroline W. Bynum, "Soul and Body", in Dictionary of the Middle Ages, Supplement, ed. William Chester Jordan (New York 2004), 588-94.

Kateřina Charvátová, Dějiny cisterckého rádu v Čechách 1142-1420 [History of the Cistercian Order in Bohemia ], 3 vols. (Prague, 1998-2009)

Anthony Cohen, The Symbolic Construction of Community (Chichester et al., 1985).

Giles Constable, "Religious Communities, 1024-1215", in The New Cambridge Medieval History, eds. David Luscombe and Jonathan Riley-Smith (Cambridge et al., 2004), $335^{-67}$.

Peter Csendes, "Urban Development and Decline on the Central Danube, 1000-160o", in Towns in Decline, AD 10oo-16oo, ed. Terry R. Slater (Aldershot, 2000), 137-53. 
Roman Czaja et al., eds., Klosterlandschaften:Methodisch-exemplarische Annäherungen

(Paderborn, 2008).

Jürgen Dendorfer, "Gescheiterte Memoria? Anmerkungen zu den 'Hausklöstern' des hochmittelalterlichen Adels”, Zeitschrift für Württembergische Landesgeschichte 73 (2014), 17-38.

Hans-Jürgen Derda, Vita communis: Studien zur Geschichte einer Lebensform in Mittelalter und Neuzeit (Cologne et al., 1992).

Albrecht Diem, Das monastische Experiment:Die Rolle der Keuschheit beiderEntstehung des westlichen Klosterwesens, Vita regularis 36 (Münster, 2005).

Heide Dienst, Regionalgeschichte und Gesellschaft im Hochmittelalter am Beispiel Österreichs, Mitteilungen des Instituts für Österreichische Geschichtsforschung, Ergänzungsband 27 (Vienna, Cologne, 1990).

Ingrid Ehlers-Kisseler, "Norm und Praxis bei den Prämonstratensern im Hochmittelalter", in Studien zum Prämonstratenserorden, eds. Irene Crusius and Helmut Flachenecker, Studien zur Germania Sacra 25 (Göttingen, 2003), 335-88.

Kaspar Elm and Michel Parisse, eds., Doppelklöster und andere Formen der Symbiose männlicher und weiblicher Religiosen im Mittelalter, Ordensstudien 8, Berliner historische Studien 18 (Berlin 1992).

Ulrich Faust and Waltraud Krassnig, eds., Die benediktinischen Mönchs- und Nonnenklöster in Österreich und Südtirol (St Ottilien, 2000-2002).

Franz Felten, "Wozu treiben wir vergleichende Ordensgeschichte?", in Mittelalterliche Orden und Klöster im Vergleich: Methodische Ansätze und Perspektiven, eds. Gert Melville and Anne Müller, Vita regularis 34 (Münster, 2007), 1-51.

Franz Felten and Werner Rösener, eds., Norm und Realität: Kontinuität und Wandel der Zisterzienser im Mittelalter (Berlin, 2009).

Franz Felten, Vita religiosa sanctimonialium: Norm und Praxis des weiblichen religiösen Lebens vom 6. bis zum 13. Jahrhundert, ed. Christine Kleinjung, Studien und Texte zur Geistes- und Sozialgeschichte des Mittelalters 4 (Korb, 2011).

Franz J. Felten, Harald Müller and Heidrun Ochs, eds., Landschaft(en): BegriffeFormen-Implikationen (Stuttgart, 2012).

Dušan Foltýn et al., eds., Encyklopedie moravských a slezských klášterů [Encyclopaedia of Moravian and Silesian Monasteries] (Prague, 2005).

John B. Freed, "Urban Development and the 'cura monialium' in Thirteenth-Century Germany", Viator 3 (1972), 311-27.

Thomas Füser, Mönche im Konflikt: Zum Spannungsfeld von Norm, Devianz und Sanktion bei den Cisterciensern und Cluniazensern: 12. bis 14. Jahrhunderts, Vita regularis 9 (Münster, 2000).

Patrick J. Geary, Phantoms of Remembrance: Memory and Oblivion at the End of the First Millenium (Princeton, 1994).

Andre Gingrich and Christina Lutter, "Visions of Community: An Introduction", History and Anthropology 26 (2015) 1-7; DOI: 10.1080/02757206.2014.930739 
Fiona J. Griffiths and Julie Hotchin, Partners in Spirit: Women, Men, and Religious Life in Germany, 1100-1500 (Turnhout, 2014).

Jeffrey F. Hamburger et al., eds., Frauen-Kloster-Kunst: Neue Forschungen zur Kulturgeschichte des Mittelalters (Turnhout, 2007).

Alfred Haverkamp, "Neue Formen von Bindung und Ausgrenzung: Konzepte und Gestaltungen von Gemeinschaften an der Wende zum 12. Jahrhundert", in Salisches Kaisertum und neues Europa: Die Zeit Heinrichs IV und Heinrichs V, eds. Bernd Schneidmüller and Stefan Weinfurter (Darmstadt, 2007), 85-122.

Elisabeth van Houts, Memory and Gender in Medieval Europe 900-1200 (London, 1999).

Elisabeth van Houts, ed., Medieval Memories: Men, Women and the Past 700-1300 (London, 2001).

Peter Johanek, "Stadt und Zisterzienserinnenkonvent: Ausblick auf ein Forschungsprogramm", in Stadtarchiv und Stadtgeschichte: Forschungen und Innovationen, ed. Archiv der Stadt Linz (Linz, 2004), 217-30.

Fritz Peter Knapp, Die Literatur des Spätmittelalters: Geschichte der Literatur in Österreich, vol. 2/1: Die Literatur des Spätmittelalters (Graz, 1999).

Frank C. Korom , ed., The Anthropology of Performance (Chichester, 2013).

Christiane Ulrike Kurz, "Ubi et est habitatio sororum et mansio fratrum": Doppelklöster und ähnliche Klostergemeinschaften im mittelalterlichen Österreich (Diözese Passau in den Ausdehnungen des 13. Jahrhunderts) (Kiel, 2015).

József Laszlovszky, "Crown, Gown and Town: Zones of Royal, Ecclesiastical and Civic Interaction in Medieval Buda and Visegrád", in Segregation-IntegrationAssimilation: Religious and Ethnic Groups in the Medieval Towns of Central and Eastern Europe, eds. Derek Keene et al. (Farnham, 2009), 179-203.

Jean Leclercq, "La clôture: Points de repère historiques", Collectanea Cisterciensia 43 (1981), 366-76.

Thomas Lentes, “Andacht und Gebärde: Das religiöse Ausdrucksverhalten”, in Kulturelle Reformation: Sinnformationen im Umbruch (1400-160o), eds. Bernhard Jussen and Craig Koslowsky, Veröffentlichungen des Max-Planck-Institutes für Geschichte 145 (Göttingen, 1998), 29-67.

ConradLeyser,AuthorityandAsceticismfromAugustinetoGregorytheGreat(Oxford,200o). Klaus Lohrmann and Ferdinand Opll, eds., Regesten zur Frühgeschichte von Wien, Forschungen und Beiträge zur Wiener Stadtgeschichte 10 (Vienna, 1981).

Radka Lomičková, "Visitationsurkunden aus böhmischen und österreichischen Zisterzienserklöstern: Das Leben hinter Klostermauern im 14. Jahrhundert", Citeaux-Commentarii cistercienses 62,1-4 (2011), 241-82.

Christina Lutter, Geschlecht\&Wissen, Norm\&Praxis, Lesen\&Schreiben: Monastische Reformgemeinschaften im 12. Jahrhundert (Vienna, 2005).

Christina Lutter, "Locus horroris et vastae solitudinis? Zisterzienser und Zisterzienserinnen in und um Wien", Historisches Jahrbuch 132 (2012), 141-76. 
Christina Lutter, "Social Groups, Personal Relations, and the Making of Communities in Medieval vita monastica", in Making Sense as Cultural Practice: Historical Perspectives, ed. Jörg Rogge (Bielefeld, 2013), 45-61.

Christina Lutter, "Comparative Approaches to Visions of Community", History and Anthropology 26 (2015), 129-43; DOI: 10.108o/02757206.2014.930738

Christina Lutter, "Geistliche Gemeinschaften in der Welt", in Klöster im Mittelalter zwischen Jenseits und Welt, eds. Gert Melville et al. (Regensburg, 2014), 145-60.

Christina Lutter, "Geteilte soziale Räume und gemeinsame Zugehörigkeiten: Die WienerZisterzienserinnenum 1300", in Konstanzund Wandel:Religiöse Lebensformen im europäischen Mittelalter, eds. Christine Kleinjung und Thomas Kohl (Korb, 2016), in press.

Jürgen Martschukat and Steffen Patzold, eds., Geschichtswissenschaft und "performative turn": Ritual, Inszenierung und Performanz vom Mittelalter bis zur Neuzeit (Cologne et al., 2003).

Brian P. McGuire, Friendship and Community: The Monastic Experience, 350-1250, 2nd ed. (Ithaca, 2010).

June Mecham, Sacred Communities, Shared Devotions: Gender, Material Culture and Monasticism in Late Medieval Germany, eds. Alison I. Beach et al., Medieval Women: Texts and Contexts 29 (Turnhout 2014).

Gert Melville and Anne Müller, eds., Regula Sancti Augustini: Normative Grundlage differenter Verbände im Mittelalter (Paring, 2002).

Gert Melville and Anne Müller, eds., Female 'vita religiosa' between Late Antiquity and the High Middle Ages: Structures, Developments and Spatial Contexts, Vita religiosa 47 (Berlin, 2011).

Gert Melville, Die Welt der mittelalterlichen Klöster: Geschichte und Lebensformen (Munich, 2012).

Gert Melville et al., eds., Innovationen durch Deuten und Gestalten: Klöster im Mittelalter zwischen Jenseits und Welt (Regensburg, 2014).

Gert Melville, "Im Spannungsfeld von religiösem Eifer und methodischem Betrieb:Zur Innovationskraft der mittelalterlichen Klöster", Denkströme:Journal der Sächsischen Akademie der Wissenschaften 7 (2011), 72-92, http://denkstroeme.de/heft-7/s_72-92_ melville (20.07.2015).

Constant Mews, "Scholastic Theology in a Monastic Milieu in the Twelfth Century: The Case of Admont", in Manuscripts and Monastic Culture: Reform and Renewal in Twelfth-Century Germany, ed. Alison I. Beach (Turnhout, 2007), 217-40.

Michael Mitterauer, "Geistliche Verwandtschaft im Kontext mittelalterlicher Verwandtschaftssysteme", in Die Familie in der Gesellschaft des Mittelalters, ed. KarlHeinz Spieß (Vorträge und Forschungen 71, Sigmaringen, 2009), 171-95.

Jörg Oberste, Visitation und Ordensorganisation: Formen sozialer Normierung, Kontrolle und Kommunikation bei Cisterziensern, Prämonstratensern und Cluniazensern (12.-frühes 14.Jh.), Vita regularis 2 (Münster, 1996). 
Otto G. Oexle, "Max Weber und das Mönchtum", in Max Webers Religionssoziologie in interkultureller Perspektive, eds. Hartmut Lehmann and Jean Martin Ouédraogo (Göttingen, 2003), 311-34.

Otto G. Oexle, Die Wirklichkeit und das Wissen: Mittelalterforschung-Historische Kulturwissenschaft_-Geschichte und Theorie der historischen Erkenntnis, eds. Andrea von Hülsen-Esch et al. (Göttingen, 2011).

Otto G. Oexle, "Koinos bios: Die Entstehung des Mönchtums", in id., Die Wirklichkeit und das Wissen: Mittelalterforschung-Historische Kulturwissenschaft_Geschichte und Theorie der historischen Erkenntnis, eds. Andrea von Hülsen-Esch et al. (Göttingen, 2011), 470-95.

Ferdinand Opll, "St. Maria bei St. Niklas vor dem Stubentor", Jahrbuch des Vereins für Geschichte der Stadt Wien 50 (1994), 13-81.

Judith A. Rasson and Katalin Szénde, eds., Annual of Medieval Studies at the Central European University (CEU) 21 (Budapest, 2015).

Diarmuid Ó Riain, "The Magnum Legendarium Austriacum: A New Investigation of one of Medieval Europe's Richest Hagiographical Collections", Analecta Bollandiana 133 (2015), 87-165; DOI 10.1484/J.ABOL.5.107710.

Hedwig Röckelein, “Inklusion—Exklusion: weiblich—männlich”, in Klöster im Mittelalter zwischen Jenseits und Welt, eds. Gert Melville et al. (Regensburg, 2014), 127-44.

Floridus Röhrig, ed., Die Stifte der Augustiner-Chorherren in Böhmen, Mähren und Ungarn (Klosterneuburg, Vienna, 1994).

Floridus Röhrig, ed., Die bestehenden Stifte der Augustiner-Chorherren in Österreich, Südtirol und Polen (Klosterneuburg, Vienna, 1997).

Floridus Röhrig, ed., Die ehemaligen Stifte der Augustiner-Chorherren in Österreich und Südtirol (Klosterneuburg, Vienna, 2005).

Werner Rösener, "Die Stadthöfe der Zisterzienser im Spannungsfeld der Stadt-LandBeziehungen des Hochmittelalters", in Kloster und Wirtschaftswelt im Mittelalter, ed. Claudia Dobrinski (Munich, 2007), 85-99.

Joachim Rössl, “Die Zwettler 'Bärenhaut' - nochmals als exemplarischer Beleg”, in Geschichtsschreibung und Geschichtsbewußtsein im späten Mittelalter, ed. Hans Patze, Vorträge und Forschungen 31 (Sigmaringen, 1987), 663-80.

Ingrid Roitner, "Das Admonter Frauenkloster im 12. Jahrhundert: Ein Musterkloster des Ordo Hirsaugiensis", Studien und Mitteilungen zur Geschichte des Bendiktiner-Ordens und seiner Zweige 116 (2005), 190-289.

Beatrix Romhany, Kolostorok és társaskáptalanok a középkori Magyarországon [Monasteries and Collegiate Chapters in Medieval Hungary] (Budapest, 200o).

Beatrix Romhany, "Kolostorhálózat—településhálózat—népesség: A középkori Magyar Királyság demográfiai helyzetének változásaihoz" [On the Demographic Changes of the Medieval Hungarian Kingdom], Történelmi Szemle 57,1 (2015), 1-49.

Barbara H. Rosenwein, Emotional Communities in the Early Middle Ages (Ithaca, 2006). 
Barbara Rosenwein, Generations of Feeling: A History of Emotions, 6oo-170o (Cambridge, 2015).

Rüdiger Schnell, "Wer sieht das Unsichtbare? Homo exterior und homo interior in monastischen und laikalen Erziehungsschriften", in 'anima' und 'sêle': Darstellungen und Systematisierungen von Seele im Mittelalter, eds. Katharina Philipowski and Anne Prior, Philologische Studien und Quellen 197 (Berlin, 2006), 83-112.

Anton E. Schönbach, "Über Gutolf von Heiligenkreuz: Untersuchungen und Texte”, in Sitzungsberichte der Kaiserlichen Akademie der Wissenschaften in Wien, phil.-hist. Klasse 150/2 (Vienna, 1904), 1-129.

Klaus Schreiner, "Consanguinitas-Verwandtschaft als Strukturprinzip religiöser Gemeinschafts- und Verfassungsbildung in Kirche und Mönchtum des Mittelalters", in Beiträge zu Geschichte und Struktur der mittelalterlichen Germania Sacra, ed. Irene Crusius (Göttingen, 1989), 176-305.

Klaus Schreiner, "Mönchsein in der Adelsgesellschaft des hohen und späten Mittelalter: Klösterliche Gemeinschaftsformen zwischen spiritueller Selbstbehauptung und sozialer Anpassung", Historische Zeitschrift 248 (1989), 557-620.

Klaus Schreiner, ed., Hirsau St. Peter und Paul 1091-1991, vol. 2: Geschichte, Lebens- und Verfassungsformen eines Reformklosters (Stuttgart, 1991).

Klaus Schreiner, "Ein Herz und eine Seele: Eine urchristliche Lebensform und ihre Institutionalisierung im augustinisch geprägten Mönchtum des hohen und späten Mittelalters", in Regula Sancti Augustini: Normative Grundlage differenter Verbände im Mittelalter, eds. Gert Melville and Anne Müller (Paring, 2002), 1-47.

Klaus Schreiner, "Communio", in id., Gemeinsam leben: Spiritualität, Lebens- und Verfassungsformen klösterlicher Gemeinschaften in Kirche und Gesellschaft des Mittelalters, Vita regularis 53 (Berlin, 2013), 205-41.

Klaus Schreiner, Gemeinsam leben: Spiritualität, Lebens- und Verfassungsformen klösterlicher Gemeinschaften in Kirche und Gesellschaft des Mittelalters, eds. Mirko Breitenstein and Gert Melville, Vita regularis 53 (Berlin, 2013).

Sita Steckel, "Networks of Learning in Byzantine East and Latin West: Methodological Considerations and Starting Points for Further Work", in Networks of Learning. Perspectives on Scholars in Byzantine East and Latin West, c. 1000-1200, ed. ead. et al (Zürich, Berlin, 2014), 185-233.

Stefanie Seeberg, DieIllustrationen im Admonter Nonnenbreviervon1180:Marienkrönung und Nonnenfrömmigkeit: Die Rolle der Brevierillustration in der Entwicklung von Bildthemen im 12. Jahrhundert (Wiesbaden, 2002).

Carole Straw, Gregory the Great: Perfection in Imperfection (Berkeley, Los Angeles, London, 1991).

Steven Vanderputten, Monastic Reform as Process: Realities and Representations in Medieval Flanders, 900-110o (Ithaca, London, 2013). 
Steven Vanderputten, "Communities of Practice and Emotional Aspects of Loyalty in Tenth and Eleventh-Century Monasticism”, in Loyalty in the Middle Ages: Ideal and Practice of a Cross-Social Value, eds. Jörg Sonntag and Coralie Zermatten (Turnhout, 2016) in press.

Pavel Vlček et al., eds., Encyklopedie českých klášterů [Encyclopaedia of Bohemian Monasteries] (Prague, 1998).

Stefan Weinfurter, Salzburger Bistumsreform und Bischofspolitik im 12.Jahrhundert:Der Erzbischof Konrad I. von Salzburg (1106-1147) und die Regularkanoniker (Cologne, 1975).

Stefan Weinfurter, "Die Macht der Reformidee: Ihre Wirkkraft in Ritualen, Politik und Moral der spätsalischen Zeit”, in Religiöse Ordnungsvorstellungen und Frömmigkeitspraxis im Hoch- und Spätmittelalter, ed. Jörg Rogge (Korb, 2008), 13-39. 